\title{
The Effects of Strategy-centered Instruction on High School Students' English Listening Competence and Self-efficacy in Korea
}

\author{
Dong-Hoon Lee ${ }^{1}$, Mun-Koo Kang ${ }^{2}$ \\ ${ }^{1}$ Teacher (Ph.D.), Cheongyang High school, South Korea, pirate31@ hanmail.net \\ ${ }^{2}$ Professor, Department of English Education, Kongju National University, South Korea, \\ kangmunkoo@hanmail.net \\ Corresponding author: Mun-Koo Kang
}

\begin{abstract}
The purpose of this study is to determine how high school English learners can improve their English listening skills by focusing on learning strategies and to think of a teaching model that could improve the English listening ability and English listening self-efficacy of high school learners. Furthermore, it aimed to examine the extent to which strategy-centered instruction could provide an advantage to the students' standardized English listening assessment score and selfefficacy for English listening competence. To do this, the study investigated practical methods of applying strategy-centered instruction that is focused on teaching English listening strategies under various theoretical background. The subjects of the study were 81 students of 2 nd grade from a high school in South Korea. As a coeducational school, there were 39 male students and 42 female students. One group of 39 students was chosen as the experimental group, and the other group of 42 students was chosen as the control group. The experimental group was focused on students' learning and using strategies for English listening. In contrast with the experimental group, the control group was taught mainly by traditional teacher-centered English listening instruction. The study was conducted for about 4 months (16 weeks). The main findings of this study can be summarized as follows: 1) It was shown that strategy-centered instruction had a positive effect on the students' English listening competence. 2) Strategy-centered instruction had a positive effect on the students' self-efficacy for English listening competence. Both results were found to be statistically significant.
\end{abstract}

Keywords: English, Strategy, Self-efficacy, English Listening, Strategy-centered Instruction, Teachercentered Instruction

\section{Introduction}

It has been several decades ago that the English curriculum in Korea has focused on communication and emphasized communication-oriented English education[1]. Since then, the English curriculum in Korea has been continuously revised as needed, and thus the 2015 Revised English curriculum in Korea presented four core competencies based on the nature of the school English curriculum: 'English communication competency', 'self-management competency', 'community competency', 'knowledge and information processing competency'[2]. In the end, it can be seen that the English curriculum in Korea focuses on improving students' communication skills. However, the reality of education in Korea is that most schools fail to move away from teacher-centered learning, content-based learning, and grade-oriented learning.

Received: April 17, 2021; $1^{\text {st }}$ Review Result: June 1, 2021; $2^{\text {nd }}$ Review Result: July 21, 2021

Accepted: August 30, 2021 
The government and society have made various efforts to emphasize the practical aspect of English, that is, the ability to communicate in English. However, the practical aspect of English learning that students or parents think of seems to be elsewhere. From a position that considers the importance of entering a higher school and finding employment right now, it is inevitable that the grades printed on the report cards in various standardized tests are more important than what the correct curriculum for teaching and learning English proposed by the country would be.

Also, the current National English curriculum in Korea specifies English education should have the systematic hierarchy depending on the grade and school level[2]. English in High school aims to deepen and develop English communication skills to understand and express English on general topics based on the English proficiency acquired in middle school by learners[2]. Even in the light of the purpose of the high school English curriculum or in the light of the common wisdom, preparing students to receive good grades in their standardized assessments is also considered as a role of current English education in school.

Through this study, the researchers tried to find a way to maximize learners' English listening ability through classes focused on problem-solving strategies that most learners need to know[3]. To this end, it is aimed to find out whether students' English listening proficiency is improved and students' selfefficacy for English listening is increased through the strategy-centered English listening class design. Finally, this study is intended to examine whether there is a positive correlation that through strategycentered English listening classes, students' English listening skills are improved, and the resultant improvement of students' self-efficacy for English listening.

In this study, taking account of the fact that College Scholastic Ability Test actually has a great influence on the direction of English instruction in general high school English education, English listening area questions of the National Combined Academic Ability Test, which has the same type as the current College Scholastic Ability Test English listening area questions are analyzed and utilized. Strategy-centered classes were conducted for a certain period of time using the data from the analysis to present effective English learning strategies suitable for each question.

The ultimate purpose of this study is to develop optimal teaching and learning models that are able to improve learners' English listening skills and English listening self-efficacy based on the results. The research questions set up to achieve the purpose of this study are as follows.

First, does the instruction focused on English listening strategies affect learners' English listening skills?

Second, does English listening strategy-centered instruction affect learners' self-efficacy in English listening learning?

\section{Theoretical Background}

\subsection{Theories related to Listening Skills and Listening Strategies}

\subsubsection{Definition of English Listening Skills}

As can be seen from Nunan's expression of English listening as "Cinderella Skill", English listening has an aspect that has not received much attention compared to English speaking[4]. In reality, however, English listening is an area where students spend more than 50 percent of the time they spend working in their second language[5]. Nevertheless, the function of English listening is taken for granted, and it can be said to be the least studied field among the four skills of English. However, Krashen and Terrell proved through experiments that language learning is effective when listening comprehension precedes speaking[6]. In addition, the various definitions of English listening skills are as follows. 
According to Chamot and Kupper define English listening as an active and conscious process in which the listener constructs meaning using information obtained from context and clues from existing background knowledge[7]. In addition, Anderson and Lynch define it as a conative and active communication process in which the listener listens to the speaker and constructs and interprets meaning by mobilizing verbal and non-verbal knowledge according to their purpose, expectations, and background knowledge[8].

\subsubsection{Classification of Listening Skills and Listening Comprehension Process}

Richard asserts that listening activities require more than linguistic knowledge, suggesting detailed listening skills for communication as 33 detailed listening skills, and Kim Jeong Ryeol summarizes the basic skills among these 33 detailed strategies as the phonetic phonological rule, sentence rule, discourse rule, and listening strategy[9][10].

Like English reading comprehension, English listening comprehension process can be classified into bottom-up processing, top-down processing, and interactive processing[11][12]. Morley proposed an interaction model that combines bottom-up and top-down[13]. In the bottom-up model of English listening comprehension, the listener uses linguistic knowledge to understand the meaning of the message. On the other hand, in the top-down model of English listening comprehension, the listener uses background knowledge to understand the meaning of the message. In the interactive model of English listening comprehension, the background knowledge of the listener in the top-down process interacts with the linguistic knowledge in the bottom-up process to understand the meaning of the message[14].

Also, Anderson argued that the English listening comprehension process has a cognitive system that goes through three stages[15]. First, in order to identify words in perceptual processing, sound units and syllable boundaries are decoded and stored in echoic memory. And in the parsing step, words and phrases are interpreted to form meanings by comparing the linguistic information stored in long-term memory with the content received in the previous step. In the last utilizing step, the English listening comprehension is completed by linking the information that the listener has with the information entered through the previous two steps. It can be said that English listening strategies are used by students reflexively in a short moment in order to promote English listening activities composed of a series of complex activities. According to the research of Rost, strategies used by successful learners are as follows: Predicting, Inferring, Monitoring, Clarifying, Responding, Evaluating[16].

When you look at the English listening comprehension process and listening strategies we have looked at so far, you can see that there are many overlapping parts. In the end, those are not activities that most listeners are conscious of all the time at each process, but it can be seen that they naturally select and use appropriate strategies according to the listening comprehension process.

\subsection{Theories related to Self-efficacy}

Self-efficacy is a concept proposed in social cognitive theory and is defined as an expectation or belief in one's ability to achieve desired results as expected by organizing and executing actions necessary to achieve a certain goal[17]. The theory of self-efficacy began to attract attention in the field of education since Schunk performed a series of experiments related to children's mathematics achievement[18]. Bandura presents three types of forms in which self-efficacy contributes significantly to the development of cognitive abilities that determine academic achievement. First, students' belief that they can achieve full maturity in a variety of subjects, and second, teachers' belief in personal efficacy that they can promote students' motivation and learning. Third, it can act on the faculty's collective efficacy expectations that schools can make meaningful academic progress[17]. 
In the end, it can be said that the treatment of the above three factors is important in order to increase learners' self-efficacy. Students who continue to fail in learning may fall into learned helplessness. Learned helplessness refers to a psychological state that appears when it is impossible to control something oneself[19]. In other words, it can be said that it is a psychological state in which an individual repeatedly experiences an uncontrollable situation and has the idea that his or her reaction cannot control the result, and the thought loses motivation and eventually makes even the performance ability difficult. A person suffering from learned helplessness experiences a decrease in self-esteem, emotional anxiety, and a sense of loneliness. The purpose of this study is to allow learners to use English language learning strategies for their own learning by treating students with classes based on English learning strategies.

\section{Research Method}

\subsection{Composition of Research Subjects}

This study was conducted with 81 students from 4 classes out of the 2nd year of a humanities coeducational high school that is located in $\mathrm{C}$ county and $\mathrm{C}$ province. As a coeducational school, there were 39 male students and 42 female students. Thirty-nine students from two classes who received instruction focused on English listening strategies were set as the experimental group, and 42 students from two classes who received traditional teacher-centered instruction were set as the control group. In each group, there is a similar proportion of male and female students.

\subsection{Research Tools}

\subsubsection{English Listening Ability Test}

English listening ability evaluation needs to be conducted with questions of similar difficulty and reliability, respectively, before and after implementing strategy-centered instruction. Therefore, the National Combined Academic Ability Test, which can be recognized to some extent, was used as a tool to assess English listening ability. In English listening area of the National Combined Academic Ability Test, there are 17 questions that have various types. The score of English listening area of the National Combined Academic Ability Test conducted in June was used as a pre-test score, and the score of English listening area of the National Combined Academic Ability Test conducted in September was used as the post-test score.

\subsubsection{English Listening Self-Efficacy Test}

In order to measure the self-efficacy for English listening, nine questions related to self-efficacy among 22 questions of the MSLQ (Motivated Strategies for Learning Questionnaire) developed by Pintrich and De Groot and The Questionnaire of English Self-Efficacy (QESE) developed by Chuang Wang, Do-Hong Kim, Mimi Mong \& Hyun Seon Ahn were selected. Afterwards, it was modified and supplemented to suit the purpose and target of this study[20][21].

\subsection{Study Design}

This study was conducted for about 4 months (16 weeks) from early June, 2020 to the end of September, 2020. The English listening strategy-focused instruction class for the experimental group and the traditional English listening instruction class for the control group were conducted using 3 hours of 5 hours of English I and II classes per week. The procedure of the study was in the order of 'pre-test $\rightarrow$ experimental treatment $\rightarrow$ post-test'. 


\subsection{Instructional Design and Method of Control Group and Experiment Group}

\subsubsection{Class Materials}

The instructional materials for this study were ensured to be highly related to the National Combined Academic Ability Test and College Scholastic Ability Test. Taking account of the needs and levels of second-year high school students, who are the subjects of this study the textbook published by EBS (Education Broadcasting System) and the previous questions on the National Combined Academic Ability Test were used. It fully reflects the types of English listening parts that are presented in the English area of the National Combined Academic Ability Test and College Scholastic Ability Test, and the same textbooks were used for both the experimental group and the control group. In addition, a list of strategies according to the types of listening questions were used to improve their English listening skills by using English listening strategies while learning the textbooks selected by the learners.

\subsubsection{Teaching Method}

This study aimed to improve English listening skills by instructing learners in the experimental group and the control group with a focus on English listening strategies. The task activities that the two groups of learners participated in at each stage of the English listening class were the same, and there was a difference in the way they were taught English listening strategies. In the experimental group, the learner was instructed to select and apply appropriate strategies from the list of strategies for the English listening questions to be learned, and in the control group, the teacher directly suggested and guided the appropriate strategies for the English listening questions.

The flow of class was largely set in the stages of introduction, development, and arrangement. In the introduction stage, students practice and learn, such as activating background knowledge and predicting content. And at this stage, the students analyzed the characteristics of the questions in the listening process to set a goal for English listening and select appropriate strategies according to the goal. In the development stage, students used the strategies selected by their own choice according to the type of question, and then checked the correct answers and their understanding. Then, students were asked to compare and evaluate the strategies they chose for each question. The strategies used by one another were evaluated and discussed and, if necessary, the strategies were revised. They also had time to share and explain the strategies they used. Teachers acted as facilitators to help students learn new information and check and evaluate students' strategies. In the reorganization stage, it was possible to check whether the goal was achieved for each question and to evaluate the overall stage and provide feedback.

\subsection{Data Analysis}

All data collected in this study was made into datasets using Micro-soft EXCEL, and were analyzed using statistical analysis program IBM SPSS ver. 25.0. Independent sample t-test was performed according to the experimental and control groups. The statistical significance level was based on .05 .

\section{Analysis of Research Results}

\subsection{Verification of Research Question 1}

Research Question 1. Does the instruction centered on English listening strategies affect learners' English listening skills? 


\subsubsection{Control and Experiment Group English Listening Ability Pre-Test Homogeneity Verification}

Before the experimental treatment for the study, to verify whether the experimental group and the control group were homogeneous groups in English listening ability, an independent sample t-test was performed on the pre-listening test scores of the students of both groups, and the results are shown in [Table 1].

[Table 1] Experimental Group - Control Group Listening Ability Pre-test Homogeneity Verification

\begin{tabular}{ccc|c|c|c|c|c}
\hline \multirow{2}{*}{ Group } & $\begin{array}{c}\text { Number } \\
\text { of students }\end{array}$ & Average & $\begin{array}{l}\text { Standard } \\
\text { deviation }\end{array}$ & $\mathrm{t}$ & $\begin{array}{c}\text { Degrees of } \\
\text { freedom }\end{array}$ & Significance Probability \\
\hline \multirow{2}{*}{ Listening } & Control & 42 & 25.98 & 6.241 & \multirow{2}{*}{0.163} & 79 & 0.871 \\
\cline { 2 - 8 } & Experiment & 39 & 25.74 & 6.624 & & & \\
\hline
\end{tabular}

As a result of the pre-test, the average score of the experimental group in English listening ability was 25.74 , and the average score of the control group was 25.98 , which was slightly higher in the control group. The $t$ value was 0.163 and the significance was .871 ( $p>.05)$, which indicates that there was no statistically significant difference in English listening ability. In other words, the experimental group and the control group can be said to be homogeneous groups in terms of English listening ability.

\subsubsection{Verification of Post-test Differences in English Listening Skills in Control and Experimental Groups}

After the experimental treatment, an independent sample t-test was conducted for the difference in post-test scores to verify that the strategy-oriented English listening class conducted in the experimental group was more effective than the traditional English listening class in the control group. The results are shown in [Table 2].

[Table 2] Experimental Group - Control Group Listening Ability Post-test Difference Verification

\begin{tabular}{ccc|c|c|c|c|c}
\hline \multirow{2}{*}{ Group } & $\begin{array}{c}\text { Number } \\
\text { of } \\
\text { students }\end{array}$ & Average & $\begin{array}{c}\text { Standard } \\
\text { deviation }\end{array}$ & $\mathrm{t}$ & $\begin{array}{c}\text { Degrees of } \\
\text { freedom }\end{array}$ & Significance probability \\
\hline \multirow{2}{*}{ Listening } & Control & 42 & 26.12 & 6.16 & - & 79 & 0.002 \\
\cline { 2 - 7 } & Experiment & 39 & 30.00 & 4.48 & 3.220 & 79 \\
\hline
\end{tabular}

As a result of the post-test, in terms of English listening ability, the average score of the experimental group was 30.00 and the average score of the control group was 26.12, which was higher in the experimental group. The $t$ value is -3.220 and the significance level is $.002(p<.05)$, so this difference can be said to be statistically significant in English listening ability. In other words, it can be said that there is a statistically significant difference between the experimental group and the control group in terms of English listening ability.

\subsection{Verification of Research Question 2}

Research Question 2. Does English Listening Strategy-Centered Lessons Affect Learners' Self-Efficacy in English Listening Learning?

\subsubsection{Control and Experiment Group English Listening Self-Efficacy Pre-Test Homogeneity}




\section{Verification}

Before the experimental treatment, to verify whether the experimental group and the control group were homogeneous groups in terms of self-efficacy for English listening, an independent sample t-test was performed on the pre-test scores, and the results are shown in [Table 3].

[Table 3] Experimental Group - Control Group English Listening Self-efficacy Pre-test Homogeneity Verification

\begin{tabular}{ccc|c|c|c|c|c}
\hline \multicolumn{2}{c}{ Group } & $\begin{array}{c}\text { Number } \\
\text { of } \\
\text { students }\end{array}$ & Average & $\begin{array}{c}\text { Standard } \\
\text { deviation }\end{array}$ & t & $\begin{array}{c}\text { Degrees of } \\
\text { freedom }\end{array}$ & Significance probability \\
\hline $\begin{array}{c}\text { Self-efficacy } \\
\text { (listening) }\end{array}$ & Control & 42 & 27.88 & 8.34 & 0.271 & 79 & 0.787 \\
\hline
\end{tabular}

As a result of the pre-test, in terms of self-efficacy for English listening, the average score of the experimental group was 27.38 , and the average score of the control group was 27.88 , which was slightly higher in the control group. The $t$ value is -0.271 , and the significance level is .787 ( $p>.05$ ), which indicates that there was no statistically significant difference in self-efficacy for English listening. In other words, the experimental group and the control group can be said to be homogeneous groups in terms of self-efficacy for English listening.

\subsubsection{Control and Experimental Group English Listening Self-efficacy Post-test Difference Verification}

After the experimental treatment, an independent sample t-test was conducted for the difference in post-test scores to verify that the strategy-based class conducted in the experimental group was more effective than the traditional listening class in the control group in terms of English listening selfefficacy. The results are shown in [Table 4].

[Table 4] Experimental Group - Control Group English Listening Self-efficacy Post-test Difference Verification

\begin{tabular}{ccc|c|c|c|c|c}
\hline \multicolumn{2}{c|}{ Group } & $\begin{array}{c}\text { Number } \\
\text { of } \\
\text { students }\end{array}$ & Average & $\begin{array}{c}\text { Standard } \\
\text { deviation }\end{array}$ & $\mathrm{t}$ & $\begin{array}{c}\text { Degrees } \\
\text { of } \\
\text { freedom }\end{array}$ & Significance probability \\
\hline $\begin{array}{c}\text { Self-efficacy } \\
\text { (listening) }\end{array}$ & Control & 42 & 28.85 & 8.74 & - & 79 & 0.000 \\
\hline
\end{tabular}

As a result of the post-test, the average score of the experimental group was 33.85 and the average score of the control group was 28.85 in terms of self-efficacy for English listening, which was higher in the experimental group. The $t$ value is -3.873 and the significance level is $.000(p<.05)$, hence this difference can be said to be significant in self-efficacy for English listening. In other words, it can be said that there is a statistically significant difference between the experimental group and the control group in terms of self-efficacy for English listening.

\section{Conclusions and Suggestion}

The theoretical background was established by reviewing literature and prior research related to the 
definition of English listening ability, English listening strategy, and self-efficacy, and the group who took strategy-centered classes for 81 second-year high school students was set as an experimental group. By setting the group who took the traditional teacher-centered English listening class as the control group, this study tried to find out what kind of teaching methods have a greater effect on the learner's English listening ability and learner's self-efficacy for English listening. The conclusions of the study based on the experimental treatment results of this study are as follows.

First, classes focusing on English listening strategies have an effect on the improvement of learners' English listening skills. Both the experimental group who took the listening strategy-oriented class and the control group who took the traditional listening class improved their English listening skills score after the experiment compared to before the experiment. Among them, the improvement of the experimental group was higher. As a result of the independent expression t-test, the difference in the degree of improvement between the two groups was found to be significant. Through this, it can be judged that the opportunity for learners to think and apply strategies suitable for each question through listening strategy-centered classes is more helpful in improving English listening skills than traditional teacher-centered classes.

Second, classes focused on English listening strategies have an effect on improving learners' selfefficacy for English listening. Both the experimental group who took the English listening strategycentered class and the control group who took the traditional English listening class improved their English listening self-efficacy score after the experiment compared to before the experiment. Among them, the improvement of the experimental group was higher. As a result of the independent expression $t$-test, the difference in the degree of improvement between the two groups was found to be significant. It can be judged that the self-efficacy for English listening is improved through the process of learning how to use English listening strategies and proving that the strategies are actually effective.

The purpose of this study is to determine how high school English learners can improve their English listening skills by focusing on learning strategies that can be used when listening to English. Furthermore, it is also intended to find out whether it had an effect on self-efficacy in English listening and to think of a teaching model that could improve the English listening ability and English listening self-efficacy of high school learners. The conduct of the study only took a period of 4 months, and it only targeted 2nd grade students in high school located in C, thus, there are limitations in that it was not possible to control all of the various variables in English learning. In order to design and apply the teaching method more effectively, the following suggestions were made:

First, teaching focused on English listening strategies is a method of teaching that meets the needs and demands of learners. If the school does not address the areas that students need and consider important, students will have no choice but to seek other means other than the school. It is also an important teaching strategy for teachers to design classes in which students can practice various strategies for listening to English in order to prepare for their future career while steadily improving their basic English skills[22]. As teachers play main role in implementing the curriculum in the real class and delivering it to the students, through continuous communication with students, teachers should grasp the current abilities, readiness, interests, and learning styles of students, and design their classes accordingly[22][23]. To do so, teachers also should have opportunities to attend relevant training or studies about English listening strategies.

Second, it was examined not only the improvement of English listening ability but also the improvement of English listening self-efficacy through English strategy-oriented classes. As mentioned earlier, self-efficacy is defined as an expectation or belief in one's ability to achieve desired results as expected by organizing and executing actions necessary to achieve a certain goal[17]. The opposite concept can be said to be learned helplessness. Learned helplessness is a psychological state that appears when you realize that you cannot control certain outcomes through your own voluntary class[19]. According to a study by Kim Bo-min, learners with higher self-efficacy toward English show lower 
anxiety, while revealing higher learning motivation[24]. On the contrary, if students feel the learned helplessness, it is difficult to expect an increase in interest and ability in learning through any class design. It is necessary to make efforts to design very detailed instruction that meets the various situations and needs of various learners so that learners can often acquire success experiences, that is, to increase their self-efficacy for English listening.

In the future, further researches are needed focusing on various variables that affect a variety of learning styles. In addition, studies on learners' ability, English self-efficacy, motivations and other various factors in reading, speaking, and writing, as well as listening to English, should be additionally conducted because these kinds of things are also an important matter when designing and executing learning and teaching in the field.

\section{References}

[1] Won Key Lee, Revisions of the national curriculum of English and challenges of English education, English Teaching, (2015), Vol.70, pp.35-52, DOI : 10.15858/engtea.70.5.201512.35

[2] Ministry of Education, English and curriculum, Ministry of Education Notice No. 2015-74 [Separate Book 14], Korea: Ministry of Education, (2015)

[3] Jong-Yoen Lee, Minjung Chei, Heejung Seo, An Exploratory Study on Learning Strategy Profiles of Middle School Freshmen in Korea, International Journal of Art and Culture Technology, (2017), Vol.1, No.2, pp.7-12.

[4] Nunan, David, Second language teaching \& learning, USA Massachusetts: Heinle \& Heinle, (1999)

[5] Nunan, David, Language teaching methodology, England: Pearson Education, (1998)

[6] D. S. Krashen, D. T. Terrell, The natural approach: language acquisition in the classroom, California: The Alemany Press, (1983)

[7] A. U. Chamot, L. Kupper, Learning Strategies in Foreign Language Instruction, Foreign Language Annals, (1989), Vol.22, No.1, pp.13-21, https://doi.org/10.1111/j.1944-9720.1989.tb03138.x

[8] A. Anderson, T. Lynch, Listening, UK: Oxford University Press, (1998)

[9] Kim Jeong-ryeol, Web-based English education, Korea: Korean Cultural History, (2003)

[10] J. C. Richards, Listening Comprehension: Approach, Design, Procedure, TESOL Quarterly, (1983), Vol.17, No.2, pp.219-240, https://doi.org/10.2307/3586651

[11] C. Chaudron, J. C. Richards, The Effect of Discourse Markers on the Comprehension of Lectures, Applied Linguistics, (1986), Vol.7, No.2, pp.113-127, https://doi.org/10.1093/applin/7.2.113

[12] Eunmi Kwon, Mun-Koo Kang, Guided Oral Reading Strategies to be a Fluent Reader, International Journal of Art and Culture Technology, (2019), Vol.3, No.1, pp.21-28.

[13] J. Moley, Current Perspectives on Improving Aural Comprehension, ESL Magazine, (1999), Vol.2, No.1, pp.15-19.

[14] Buck, Gary, Assessing listening, England: Cambridge University Press, (2001)

[15] J. R. Anderson, Cognitive psychology and its implications. 4th Edition, USA New York: W. H. Freeman and Company, (1995)

[16] M. Rost, Teaching and Researching Listening, USA New York: Pearson Education, (2002)

[17] A. Bandura, Self-efficacy: Toward a unifying theory of behavioral change, Psychological Review, (1977), Vol.84, No.2, pp.191-215, https://doi.org/10.1037/0033-295X.84.2.191

[18] D. H. Schunk, Self-efficacy perspective on achievement behavior, Educational Psychologist, (1984), Vol.19, No.1, pp.48-58, https://doi.org/10.1080/00461528409529281 
[19] Seligman, Martin E. P, Helplessness: on depression, development, and death, USA California: W. H. Freeman, (1975)

[20] P. R. Pintrich, E. V. de Groot, Motivational and self-regulated learning components of classroom academic performance, Journal of Educational Psychology, (1990), Vol.82, No.1, pp.33-40.

[21] C. Wang, D. H. Kim, M. Bong, H. S. Ahn, Examining measurement properties of an English Self-Efficacy scale for English language learners in Korea, International Journal of Educational Research, (2013), Vol.59, No.4, pp.24-34.

[22] Eun-Sok Won, Cognition of the Teachers for Continuity in English Curriculum between Elementary and Secondary School in South Korea, Asia-Pacific Journal of Educational Management Research, (2016), Vol.1, No.1, pp.89-94.

[23] Lae-Ok Jeong, Mun-Koo Kang, Yong-Myeong Kim, The direction of 'Flipped classroom' based on prospective study analysis, Asia-Pacific Journal of Educational Management Research, (2016), Vol.1, No.1, pp.63-70.

[24] Kim Bo-min, The relationship between English self-efficacy and English proficiency, motivation for learning, and anxiety, Yonsei University, Master's Thesis, (2016) 